\title{
Characterization of Size Distribution and Concentration of Atmospheric Particles During Summer in Zhuzhou, China
}

\author{
Jinhe Wang, ${ }^{1,2}$ Xi Zhang ${ }^{1,3}$, Kai Zhang ${ }^{3 *}$, Zilong Zheng ${ }^{3,4}$ \\ ${ }^{1}$ School of Municipal and Environmental Engineering, Shandong Jianzhu University, Jinan, China \\ ${ }^{2}$ Shandong Provincial Co-Innovation Center of Green Building, Jinan, China \\ ${ }^{3}$ State Key Laboratory of Environmental Criteria and Risk Assessment, Chinese Research Academy \\ of Environmental Sciences, Beijing, China \\ ${ }^{4}$ Department of Chemistry and Environmental Engineering, Shandong University of Science and Technology, \\ Qingdao, China
}

Received: 16 August 2017

Accepted: 21 November 2017

\begin{abstract}
In order to provide a sound basis for the performance evaluation of a local government's air pollution prevention and abatement measures, the mass concentrations of $\mathrm{PM}_{2.5}$ and $\mathrm{PM}_{10}$ and the concentrations of different sized particles were measured in August 2013. Meanwhile, the influencing factors and sources of atmospheric particulate matters were analyzed by combining meteorological factors and gaseous pollutants. The results indicated that $\mathrm{PM}_{2.5}$ and $\mathrm{PM}_{10}$ in Zhuzhou were $(30.3 \pm 12.2) \mu \mathrm{g} \cdot \mathrm{m}^{-3}$ and $(56.4 \pm 26.6) \mu \mathrm{g} \cdot \mathrm{m}^{-3}$, respectively. The mean values of the particle number concentration in the size range of $0.5 \sim 1 \mu \mathrm{m}$ and $1 \sim 2.5 \mu \mathrm{m}$ on sunny days were $(121.2 \pm 75.9) \mathrm{cm}^{-3}$ and $(6.8 \pm 3.7) \mathrm{cm}^{-3}$, respectively, whereas in the rainy days they sharply increased to $(868.7 \pm 262.1) \mathrm{cm}^{-3}$ and $(347.9 \pm 238.6) \mathrm{cm}^{-3}$, which accounted for $71.0 \%$ and $28.4 \%$ of the total number of concentrations, respectively. Backward trajectory analysis demonstrated that the air masses in Zhuzhou city mainly came from three directions: southeast (52.2\%), southwest (24.7\%), and northeast (23.1\%). Although accounting for a minor fraction, the northeast air mass had the largest effect on particle concentrations in Zhuzhou and also carried a lot of gaseous primary pollutants.
\end{abstract}

Keywords: size distribution, number concentration, mass concentration, hygroscopic growth, backward trajectory, cluster analysis, Zhuzhou City

*e-mail: zhangkai@craes.org.cn 


\section{Introduction}

The mass and number concentration and size distribution of atmospheric particulate matters are an important basis for assessing ambient air quality and provide significant information for understanding the impact of particulate matters on climate, ecology, and human health [1-6]. Based on the differences among the specific concentrations of particulate matter in each city, the effectiveness of the environmental measures being implemented can be evaluated and adjusted scientifically. Particle concentration and size distribution are closely related to its physical and chemical properties, residence time, and transport distance in the atmosphere. The proportion of particles with different sizes was significantly different in the mass concentration and number concentration. At present, it is difficult to provide comprehensive information about particulate matter based on the conventional monitoring of mass concentration that are normally operated by provincial government ambient air quality monitoring stations. Therefore, the study of particle number concentration is of great significance and has received widespread attention [7-9]. Over the past several years, the size distribution and concentration of atmospheric particles have been widely studied in urban or rural areas at home and abroad. Bullard et al. [8] observed the characterization of the particle size distribution and related air quality at a rural location in the continental U.S. (Bondville, Illinois $40.05^{\circ} \mathrm{N}$ and $88.37^{\circ} \mathrm{W}$ ) for the period July 2013June 2014. Zhang et al. [10] and Shen et al. [3] studied the particle number size distribution and the new particle formation (NPF) events in Lanzhou and Jiaxing, China; Zhang et al. [11] studied the size distribution of particles and their impact on visibility in urban Guangzhou during spring; Lang et al. [12] and Zhao et al. [13] analyzed the characteristics of the particle size distribution and the influence of meteorological conditions; Li et al. [14] observed the concentration of atmospheric particulate matter in different sizes in Qingdao, China, and discussed the variation characteristics under different weather conditions and air mass sources.

Zhuzhou is a traditional heavy industry city and one of the most important transportation hubs in China. Belonging to the Chang-Zhu-Tan Metropolitan Region (a group of cities of which Changsha, Zhuzhou, and Xiangtan are the cores), Zhuzhou is the focus of interregional joint air pollution prevention and control. After implementation of the new national ambient air quality standard (GB3095-2012, China), the main pollutants in Zhuzhou are found to be mainly $\mathrm{PM}_{2.5}$ and $\mathrm{PM}_{10}$; moreover, fine particulate matter has become the main factor affecting air quality. Yang et al. [15] and Zhang et al. [16] studied the particulate matter in autumn and winter in Zhuzhou, but the related research in summer is insufficient, and more importantly the information is rather limited regarding particle size distribution and the underlying variation trends. In addition, most of the current research only focuses on the particle mass concentration and the lack of complementary studies on the number, concentration, and size distribution of particulate matter, especially in central China. Therefore, it is important to measure the concentration and size distribution of particles in summer in Zhuzhou, a typical inland heavy industry city in an established city cluster in central China.

In the present study, based on the data of particle concentration, gaseous pollutant concentrations and local meteorological conditions, a scientific basis is provided for assessing the effectiveness of air pollution prevention

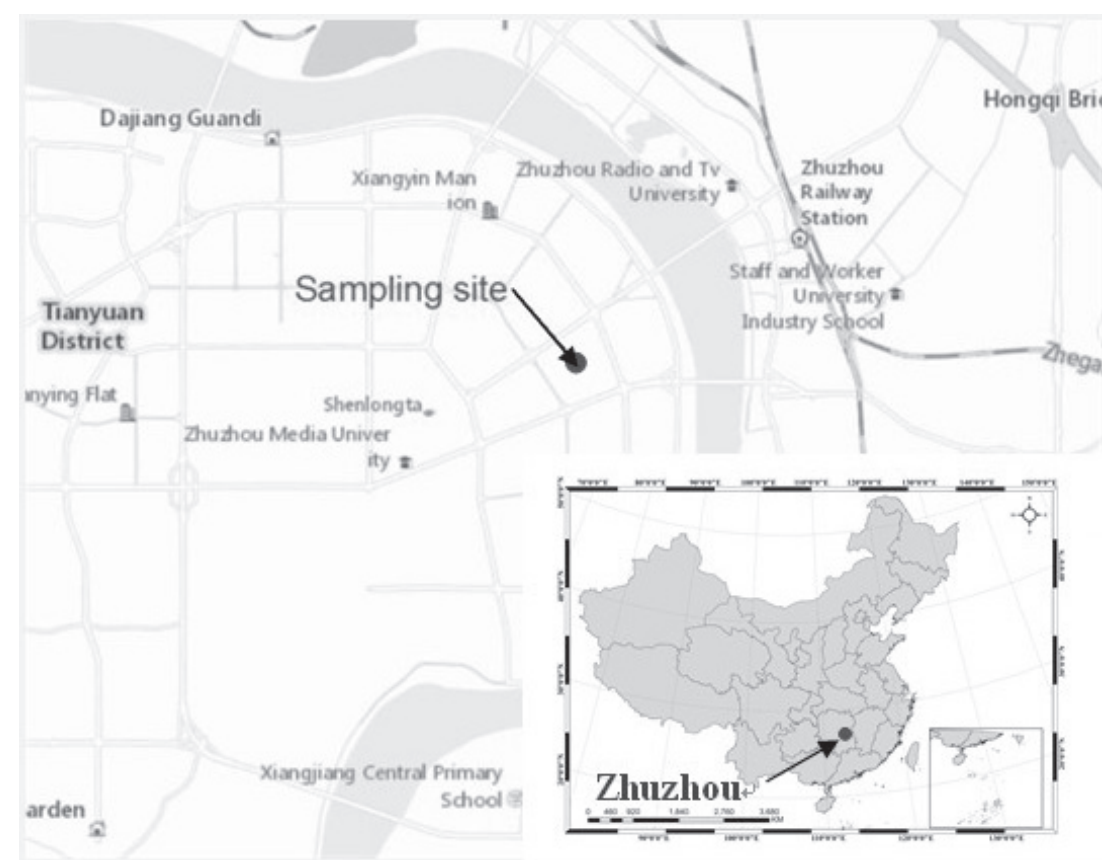

Fig. 1. Location of sampling site in Zhuzhou. 
measures for the local government, and supporting data for optimizing inter-regional joint environment policies for air pollution prevention and control and as well for air quality improvement in big city clusters, taking the Chang-Zhu-Tan Metropolitan Area as an example. The objectives of this study were detailed as follows: 1) to investigate atmospheric particle number concentration, mass concentration of $\mathrm{PM}_{10}$ and $\mathrm{PM}_{25}$, and particle size distribution in Zhuzhou in good weather during summer; 2) to assess the influence of different weather conditions on the number concentrations of particulate matter; 3) to compare particle pollution levels of Zhuzhou with other cities in China; and 4) to identify potential pollution sources and transport of atmospheric particulate matter in Zhuzhou using the backward trajectory cluster analysis method.

\section{Material and Methods}

\section{Sampling Site and Time}

The sampling site in this study was located in Zhuzhou $\left(26^{\circ} \mathrm{N}-28^{\circ} \mathrm{N}, 112.6^{\circ} \mathrm{E}-114^{\circ} \mathrm{E}\right)$, the second largest city in Hunan Province, situated in central mainland China with local weather greatly influenced by the prevalence of subtropical humid monsoon. Zhuzhou, belonging to the Chang-Zhu-Tan Metropolitan Region, is a typical heavy industry base and one of the most important transportation hubs in China, and has been undergoing accelerated industrialization and urbanization over the past several decades, which also led to severe air pollution.

The sampling site was on the 6th roof of a building

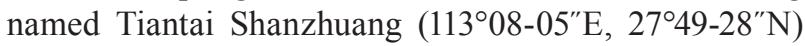
located in the center of Tianyuan District, Zhuzhou, as illustrated in Fig. 1. There is also one ambient air quality automatic monitoring sub-station on Tiantai Shanzhuang. The instrument (APS3321) was situated approximately $15 \mathrm{~m}$ above ground and the air intake was $2 \mathrm{~m}$ above the roof. The measurement campaign was conducted during summer in Zhuzhou 8-22 August 2013.

\section{Instruments and Methods}

The instrument APS3321 (Aerodynamic Particle Sizer Spectrometer 3321, produced by TSI corporation, U.S.A) was used to continuously observe the particle number concentration and size distribution. The work principle is that particle size information can be obtained by the relationship between the particle aerodynamic size and its velocity after vacuum expansion. The measured particle size ranged from 0.5 to $20.0 \mu \mathrm{m}$ with a sampling flow rate of $5 \mathrm{~L} \cdot \mathrm{min}^{-1}$ and gas flow rate of $1 \cdot \mathrm{L} \mathrm{min}^{-1}$ [17-18]. During the experiment, the concentration data of $\mathrm{SO}_{2}$, $\mathrm{CO}, \mathrm{NO}_{2}, \mathrm{O}_{3}, \mathrm{PM}_{10}$, and $\mathrm{PM}_{2.5}$ were also collected from the online monitoring instruments at the sampling site. More information associated with the instruments (detection limit, precision, and calibration) and data processing can be found in previous reports [16]. The meteorological parameters (temperature, relative humidity, wind speed, wind direction, and pressure) were measured hourly by the local meteorological department of Zhuzhou, Hunan Province.

36-h backward trajectories of air masses arriving at the sampling site were calculated using the hybrid single particle lagrangian integrated trajectory (HYSPLIT) model to investigate the influence of different air masses from distant sources on aerosol composition in Zhuzhou [19]. The meteorological data used to run the model are available at global data assimilation system (GDAS). For each sampling day, the model was run with the interval of every hour and the starting height was set as $500 \mathrm{~m}$. The method used in trajectory clustering was based on the GIS-based software TrajStat to determine the main source direction and passage area of air mass [20-21].

\section{Results and Discussion}

\section{Concentrations of Particles in Different Sizes}

The $\mathrm{PM}_{2.5}$ and $\mathrm{PM}_{10}$ concentrations in Zhuzhou were $(30.3 \pm 12.2) \mu \mathrm{g} \cdot \mathrm{m}^{-3}$ and $(56.4 \pm 26.6) \mu \mathrm{g} \cdot \mathrm{m}^{-3}$, respectively, not exceeding Grade II level of the daily average value recommended by the latest National Ambient Air Quality Standards (GB3095-2012, China - daily average value for $\mathrm{PM}_{10}$ Grade I level: $50 \mu \mathrm{g} \cdot \mathrm{m}^{-3}$; Grade II level: $150 \mu \mathrm{g} \cdot \mathrm{m}^{-3}$; daily average value for $\mathrm{PM}_{2.5}$ Grade I level: $35 \mu \mathrm{g} \cdot \mathrm{m}^{-3}$; Grade II level: $75 \mu \mathrm{g} \cdot \mathrm{m}^{-3}$ ). Furthermore, the mean ratios of $\mathrm{PM}_{2.5} / \mathrm{PM}_{10}$ in our tests were calculated at about $53.7 \%$ (Table 1), revealing that the fine particles and coarse particles accounted for similar proportion on mass concentration in Zhuzhou. In addition, the proportion of the particle number concentration of 10 20 $\mu \mathrm{m}$ was very small and therefore could be neglected. In order to conveniently compare the particle number concentration and mass concentration of $\mathrm{PM}_{2.5}$ and $\mathrm{PM}_{10}$, the particles were divided into groups of different sizes $(0.5 \sim 1.0 \mu \mathrm{m}, \quad 1.0 \sim 2.5 \mu \mathrm{m}$, and 2.5 10 $\mu \mathrm{m}$, respectively), represented by $\mathrm{PN}_{0.5 \sim 1}$, $\mathrm{PN}_{1 \sim 2.5}$, and $\mathrm{PN}_{2.5 \sim 10}$. During the observation period, the mean value of the particle number concentration of $0.5 \sim 10 \mu \mathrm{m}$ was $(461.9 \pm 127.8) \mathrm{cm}^{-3} . \mathrm{PN}_{0.5 \sim 1}, \mathrm{PN}_{1 \sim 2.5}$, and $\mathrm{PN}_{2.5 \sim 10}$ were $(334.3 \pm 74.2) \mathrm{cm}^{-3},(124.6 \pm 55.5) \mathrm{cm}^{-3}$, and (3.0土1.8) $\mathrm{cm}^{-3}$, accounting for $72.3 \%, 27.0 \%$, and $0.7 \%$ of the total number concentration, respectively (Table 1). The above data demonstrated that the particle number concentration in Zhuzhou was mainly localized in particle size of below $2.5 \mu \mathrm{m}$, and the proportion of particles below $1 \mu \mathrm{m}$ is the largest. In this study, the ratio of fine particle number concentration measured on sunny days was similar to that in other literature [3, 11, 22-24], and the concentration of particles below $1 \mu \mathrm{m}$ exceeded $90 \%$ of the total concentration (Table 2). However, compared with the data of sunny days, the proportion of $\mathrm{PN}_{1 \sim 2.5}$ in rainy days is significantly increased, which is probably due to the hygroscopic growth of aerosol particles $[12,25]$. 
Table 1. Hourly values of particle number concentration and mass concentration in different sizes.

\begin{tabular}{|c|c|c|c|c|c|}
\hline Particle size range & Mean value & Standard deviation & Maximum value & Minimum value & Ratio \\
\hline $\mathrm{PN}_{0.5 \sim 1}^{*}$ & 334.3 & 74.2 & 507.4 & 244.9 & $72.3 \%$ \\
\hline $\mathrm{PN}_{1 \sim 2.5}^{*}$ & 124.6 & 55.5 & 245.5 & 63.3 & $27.0 \%$ \\
\hline $\mathrm{PN}_{2.5 \sim 10}^{*}$ & 3.0 & 1.8 & 7.9 & 1.0 & $0.7 \%$ \\
\hline $\mathrm{PN}_{0.5 \sim 10}^{*}$ & 461.9 & 127.8 & 760.8 & 309.2 & $100.0 \%$ \\
\hline $\mathrm{PM}_{2.5}^{* *}$ & 30.3 & 12.2 & 55.5 & 13.1 & $53.7 \%$ \\
\hline $\mathrm{PM}_{10}{ }^{* *}$ & 56.4 & 26.6 & 121.0 & 31.3 & $100.0 \%$ \\
\hline
\end{tabular}

Note: *Unit $\left(\mathrm{cm}^{-3}\right),{ }^{* *}$ Unit $\left(\mu \mathrm{g} / \mathrm{m}^{3}\right)$

Table 2. Hourly values of particle number concentration and mass concentration in different sizes.

\begin{tabular}{|c|c|c|c|c|}
\hline \multirow{2}{*}{$\begin{array}{c}\text { Particle } \\
\text { size range }\end{array}$} & \multicolumn{2}{|c|}{ Mean value } & \multicolumn{2}{c|}{ Ratio } \\
\cline { 2 - 5 } & $\begin{array}{c}\text { Sunny } \\
\text { days }\end{array}$ & $\begin{array}{c}\text { Rainy } \\
\text { days }\end{array}$ & $\begin{array}{c}\text { Sunny } \\
\text { days }\end{array}$ & $\begin{array}{c}\text { Rainy } \\
\text { days }\end{array}$ \\
\hline $\mathrm{PN}_{0.5 \sim 1}^{*}$ & 121.2 & 868.7 & $94.20 \%$ & $71.00 \%$ \\
\hline $\mathrm{PN}_{1 \sim 2.5}^{*}$ & 6.8 & 347.9 & $5.30 \%$ & $28.40 \%$ \\
\hline $\mathrm{PN}_{2.5 \sim 10}^{*}$ & 0.7 & 7.8 & $0.50 \%$ & $0.60 \%$ \\
\hline $\mathrm{PM}_{2.5}^{* *}$ & 24.1 & 48.9 & $57.10 \%$ & $48.10 \%$ \\
\hline $\mathrm{PM}_{10}^{* *}$ & 42.2 & 101.6 & $100 \%$ & $100 \%$ \\
\hline
\end{tabular}

Note: *Unit $\left(\mathrm{cm}^{-3}\right),{ }^{* *}$ Unit $\left(\mu \mathrm{g} / \mathrm{m}^{3}\right)$

Compared with data on sunny days, the particle number concentration and mass concentration in different size range obviously varied in rainy days, and the variety of the fine particle number concentration was more significant than that of other sizes (Table 2, Fig. 2). From sunny to rainy days, the number concentration of particles in each size range all showed a tendency to increase.
$\mathrm{PN}_{0.5 \sim 1}$ increased to $(868.7 \pm 262.1) \mathrm{cm}^{-3}$ on rainy days, reaching about 7 times $(121.2 \pm 75.9) \mathrm{cm}^{-3}$ on sunny days, while $\mathrm{PN}_{1 \sim 2.5}$ increased to $(347.9 \pm 238.6) \mathrm{cm}^{-3}$ on rainy days, reaching about 51 times $(6.8 \pm 3.7) \mathrm{cm}^{-3}$ on sunny days. However, the ratio of the particle number concentration in each size range was different. The proportion of $\mathrm{PN}_{0.5 \sim 1}$ decreased from $94.2 \%$ on sunny days to $71.0 \%$ on rainy days, while the proportion of $\mathrm{PN}_{1 \sim 2.5}$ increased from 5.3\% to $28.4 \%$. From sunny to rainy days, the concentration of $\mathrm{PM}_{10}$ increased to $101.6 \mu \mathrm{g} / \mathrm{m}^{3}$, reaching about 2.5 times $42.2 \mu \mathrm{g} / \mathrm{m}^{3}$ on sunny days, and $\mathrm{PM}_{2.5}$ increased to $48.9 \mu \mathrm{g} / \mathrm{m}^{3}$, reaching about 2 times $24.1 \mu \mathrm{g} / \mathrm{m}^{3}$ on sunny days. In addition, the $\mathrm{PM}_{25} / \mathrm{PM}_{10}$ ratio decreased from $57.1 \%$ to $48.1 \%$. The significant difference of particle size distribution between the sunny and rainy days was mainly related to the variety of meteorological factors that affected the concentration of atmospheric particulate matter by the process of accumulation, diffusion, and removal of particulate matter, as well as atmospheric chemistry processes [26-28]. The air mass of the south direction 19-21 August caused rainfall in Zhuzhou, resulting in an increase in relative humidity and decrease in temperature. When the relative humidity does not exceed $60-70 \%$, the increase of the particle concentration

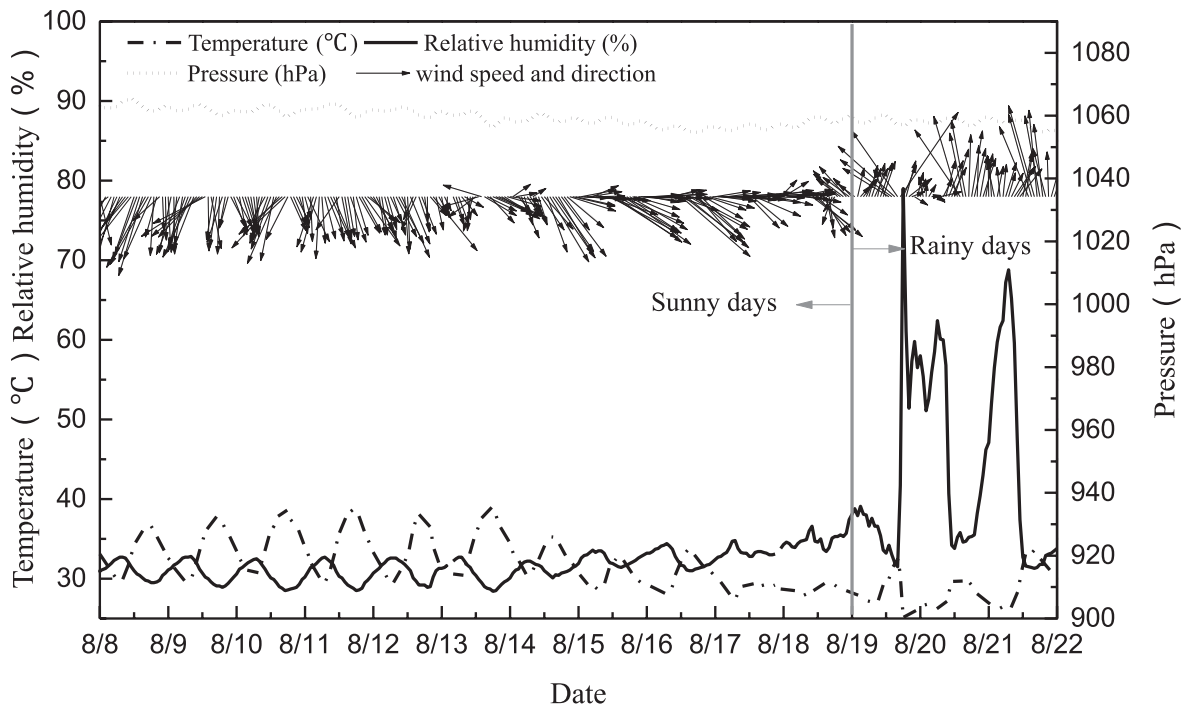

Fig. 2. Variation of meteorological factors during sampling period. 
Table 3. Comparison of particle number concentration in different regions.

\begin{tabular}{|c|c|c|c|c|}
\hline \multirow{2}{*}{ Region (sampling time) instrument } & \multicolumn{3}{|c|}{ Particle size range } & \multirow{2}{*}{ References } \\
\cline { 2 - 4 } & $\mathrm{PN}_{0.5 \sim 1}$ & $\mathrm{PN}_{1 \sim 2.5}$ & $\mathrm{PN}_{2.5 \sim 10}$ & \multirow{2}{*}{ (Qian et al., 2008) [39] } \\
\hline Nanjing (July-Dec. 2006) WPS & 666.0 & 7.0 & $\mathrm{~N} / \mathrm{A}$ & (Zhang et al., 2010) [11] \\
\hline Guangzhou (March-May 2008) APS & 127.7 & 10.3 & 1.0 & (Zhuo et al., 2011) [40] \\
\hline Shijiazhuang (May 2015) WPS & 535.0 & 19.0 & 0.7 & (Zhao et al., 2012) [13] \\
\hline Lanzhou (Aug.-Oct. 2010) APS & 98.1 & 8.5 & 1.5 & (Wang et al., 2014)[24] \\
\hline Mount Huang (June-Aug. 2011) APS & 19.6 & 1.0 & 0.1 & This study \\
\hline Zhuzhou (Aug. 2013) APS & 334.3 & 124.6 & 3.0 & \\
\hline
\end{tabular}

Note: Unit $\left(\mathrm{cm}^{-3}\right)$

Table 4. Comparison of particle mass concentration in different regions.

\begin{tabular}{|c|c|c|c|c|}
\hline \multirow{2}{*}{ Region (Sampling time) } & \multicolumn{3}{|c|}{ Particle size range } & \multirow{2}{*}{ References } \\
\hline & $\mathrm{PM}_{2.5}$ & $\mathrm{PM}_{10}$ & $\mathrm{PM}_{2.5} / \mathrm{PM}_{10}$ & \\
\hline Beijing (July 2013) & 146.0 & 214.0 & $68.2 \%$ & (Dao et al., 2015) [32] \\
\hline Guangdong (Aug. 2012) & 38.1 & 57.8 & $66.0 \%$ & (Yin et al., 2017) [41] \\
\hline Nanjing (July-Sept. 2014) & 34.6 & 70.6 & $49.0 \%$ & (Chen et al., 2016) [26] \\
\hline Hefei (Aug. 2014) & 70.4 & 110.8 & $63.5 \%$ & (Chen et al., 2016) [34] \\
\hline Wuhan (June-Aug. 2013) & 52.0 & 59.0 & $88.1 \%$ & (Zhang et al., 2015) [35] \\
\hline Changsha (Aug. 2014) & 52.5 & 84.0 & $62.5 \%$ & (Xie et al., 2016) [37] \\
\hline Xiangtan (Aug. 2014) & 49.5 & 70.0 & $70.7 \%$ & (Xie et al., 2016) [37] \\
\hline Nanling (June 2013) & 5.2 & 9.6 & $54.2 \%$ & (Zhang et al., 2015) [33] \\
\hline Haikou (April 2012) & 20.7 & 35.1 & $59.0 \%$ & (Fang et al., 2017) [20] \\
\hline Zhengzhou (July 2015) & 102 & 164 & $62.2 \%$ & (Wang et al., 2017) [22] \\
\hline Zhuzhou (Aug. 2013) & 30.3 & 56.4 & $53.7 \%$ & This study \\
\hline
\end{tabular}

Note: Unit $\left(\mu \mathrm{g} / \mathrm{m}^{3}\right)$

is caused by hygroscopic growth and secondary reactions $[12,29-30]$. Chemical compositions of particles in different sizes can cause a difference of hygroscopicity, especially strong hygroscopic substance such as watersoluble ions accounting for a larger proportion in fine particles, particularly at the size of 1-2.5 $\mu \mathrm{m}$, which could explain the sharp increase of particle concentrations on rainy days in Zhuzhou [31].

\section{Comparison with Other Cities}

The level of particle concentration in Zhuzhou was compared with megacities in the Beijing-TianjinHebei Metropolitan Region and the Pearl River Delta Metropolitan Region, which are the most developed regions in China, and with background area and other important industrial cities (Table 3, Table 4). The concentration of particulate matter in Beijing-TianjinHebei Region (for example in Beijing) was 4-5 times that in Zhuzhou City, and the proportion of $\mathrm{PM}_{2.5}(68.2 \%)$ was much higher than that in Zhuzhou [32]. The level of particle concentration in the Pearl River Delta (belonging to Guangdong Province) was not high, and the air quality was relatively better than Zhuzhou. For example, in Guangzhou (capital city of Guangdong Province), $\mathrm{PN}_{0.5 \sim 1}$ and $\mathrm{PN}_{1 \sim 2.5}$ were $127.7 \mathrm{~cm}^{-3}$ and $10.3 \mathrm{~cm}^{-3}$, and the particle mass concentration was similar to that in Zhuzhou [11]. Compared with Mount Huang, Nanling, Haikou, and other background city sites, the particle concentration in Zhuzhou is slightly higher than these cities [20, 24, 33].

Zhuzhou is an industrial city similar to other industrial cities (Nanjing, Wuhan, Hefei and Zhengzhou) in terms of industrial structure, among which particle concentration and particle size distribution of Zhuzhou is most similar to that of Nanjing [22, 26, 34-35]. Within the Chang-Zhu-Tan Metropolitan Region, the concentration of particulate matter in Zhuzhou is the same as that in Changsha and Xiangtan [36-37] (these 3 cities are contiguous and all belong to the same metropolitan region), but the $\mathrm{PM}_{2.5} / \mathrm{PM}_{10}$ ratios are significantly different. Because the particle concentration and size distribution changes a lot in different cities within one whole region, 


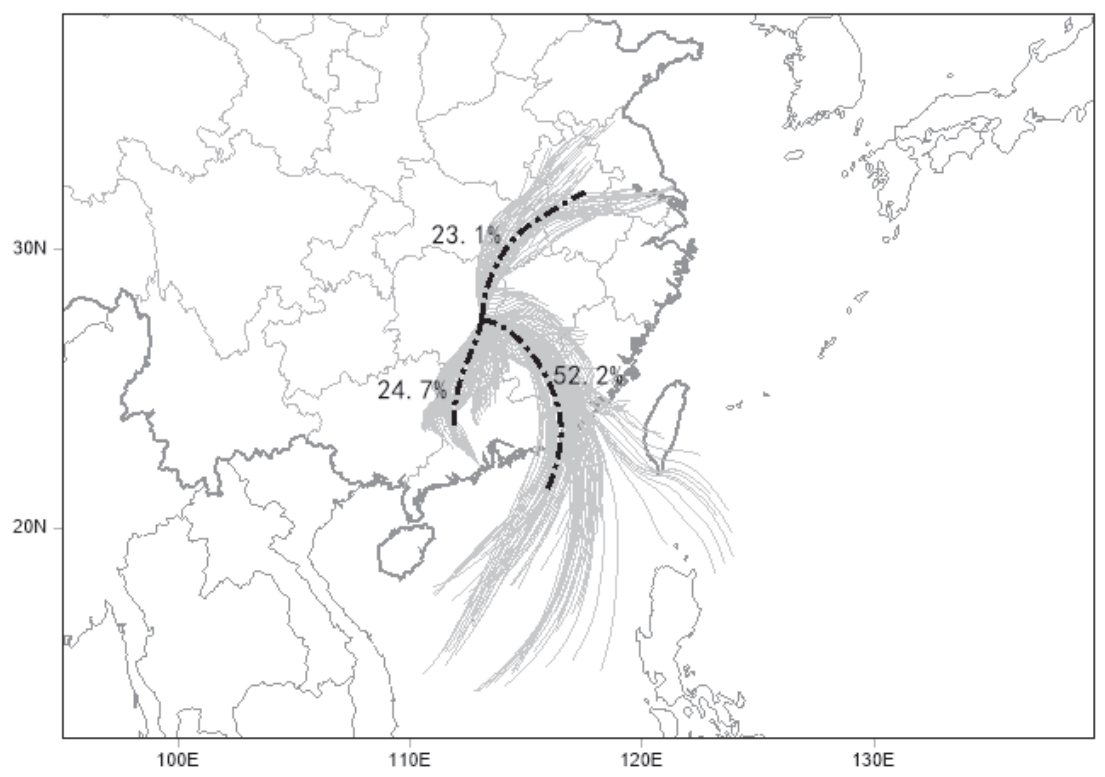

Fig. 3. Backward trajectory cluster analysis result of air mass sources in Zhuzhou.

the inter-regional joint air pollution prevention and control measures should take full account of their different levels of particle concentration in adjacent cities. According to the different sources and proportions of particulate matter in different size ranges, the reasonable formulation and adjustment of environmental measures will play an important role in improving air quality in local city and adjacent regions [38]. The findings presented here can provide an improved scientific basis on particulate matter for the local government of Zhuzhou to develop further environmental regulations for air quality improvement.

\section{Backward Trajectory Clustering Analysis}

Backward trajectory analysis showed that the air masses in Zhuzhou mainly came from 3 directions (southeast, southwest, and northeast), going through different areas. The air mass from southeast of Zhuzhou had the highest proportion (52.2\%), the second was the air mass from the southwest passing the center of Guangdong Province (24.7\%), and the last was the air mass from the northeast (23.1\%; Fig. 3). The clustering analysis of the air pollutants $\left(\mathrm{CO}, \mathrm{NO}_{2}, \mathrm{SO}_{2}, \mathrm{O}_{3}, \mathrm{PM}_{2.5}\right.$, and $\left.\mathrm{PM}_{10}\right)$ and the mean values of $\mathrm{PN}_{0.5 \sim 1}, \mathrm{PN}_{1 \sim 2.5}$, and $\mathrm{PN}_{2.5 \sim 10}$ (Tables 5-6) showed that $\mathrm{PN}_{0.5 \sim 1}, \mathrm{PN}_{1 \sim 2.5}$, and $\mathrm{PN}_{2.5 \sim 10}$ from the northeast air mass were maximum among 3 cluster directions, namely $868.7 \mathrm{~cm}^{-3}, 347.9 \mathrm{~cm}^{-3}$, and $7.8 \mathrm{~cm}^{-}$ ${ }^{3}$, respectively; the concentrations of $\mathrm{CO}, \mathrm{NO}_{2}, \mathrm{SO}_{2}$, $\mathrm{PM}_{2.5}$, and $\mathrm{PM}_{10}$ from the northeast air mass also reached the highest, which are $1.0 \mu \mathrm{g} \cdot \mathrm{m}^{-3}, 36.5 \mu \mathrm{g} \cdot \mathrm{m}^{-3}, 36.7 \mu \mathrm{g} \cdot \mathrm{m}^{-3}$, $49.0 \mu \mathrm{g} \cdot \mathrm{m}^{-3}$, and $101.6 \mu \mathrm{g} \cdot \mathrm{m}^{-3}$, respectively. This revealed that although accounting for the smallest proportion, the air mass from the northeast had the largest effect on particle concentration and also carried a lot of gaseous pollutants. The air masses from the southwest and southeast show similarities on the concentration of particle and air pollutants except that the $\mathrm{PN}_{0.5 \sim 1}$ from the southeast is about twice that from the southwest. In conclusion, compared with the particulate mass concentration and number concentration in Zhuzhou, the air masses from the southwest and southeast were relatively clean, while the "dirty" air mass from the northeast direction seriously affected the particle concentration in Zhuzhou. The air mass from the northeast going through Nanjing, Hefei, and Wuhan in sequence and other important cities eventually arrived in Zhuzhou, and the particulate matter levels of these cities were much higher than

Table 5. Statistics of particle average number concentration in different sizes under different directions.

\begin{tabular}{|c|c|c|c|}
\hline & $\mathrm{PN}_{0.5 \sim 1}$ & $\mathrm{PN}_{1 \sim 2.5}$ & $\mathrm{PN}_{2.5 \sim 10}$ \\
\hline Direction & $\begin{array}{c}\text { Mean value } \\
\pm \text { standard } \\
\text { deviation }\end{array}$ & $\begin{array}{c}\text { Mean value } \\
\pm \text { standard } \\
\text { deviation }\end{array}$ & $\begin{array}{c}\text { Mean value } \\
\pm \text { standard } \\
\text { deviation }\end{array}$ \\
\hline Southwest & $75.2 \pm 31.2$ & $7.0 \pm 2.5$ & $0.7 \pm 0.2$ \\
\hline Northeast & $868.7 \pm 264.8$ & $347.9 \pm 241.2$ & $7.8 \pm 6.7$ \\
\hline Southeast & $135.4 \pm 80.4$ & $6.8 \pm 4.1$ & $0.7 \pm 0.3$ \\
\hline
\end{tabular}

Note: Unit $\left(\mathrm{cm}^{-3}\right)$

Table 6. Statistics of atmospheric pollutants' average concentrations under different directions.

\begin{tabular}{|c|c|c|c|c|c|c|}
\hline Direction & $\mathrm{PM}_{2.5}$ & $\mathrm{PM}_{10}$ & $\mathrm{CO}$ & $\mathrm{NO}_{2}$ & $\mathrm{SO}_{2}$ & $\mathrm{O}_{3}$ \\
\hline Southwest & 23.6 & 35.1 & $0.8 * 10^{3}$ & 22.6 & 9.3 & 77.2 \\
\hline Northeast & 49.0 & 101.6 & $1.0 * 10^{3}$ & 36.5 & 36.7 & 76.6 \\
\hline Southeast & 24.7 & 46.9 & $0.8 * 10^{3}$ & 22.6 & 14.6 & 67.4 \\
\hline
\end{tabular}

Note: Unit $\left(\mu \mathrm{g} / \mathrm{m}^{3}\right)$ 
Zhuzhou (Tables 3-4) [26, 34-35]. This was consistent with the results of the backward trajectory clustering in northeastern air mass, which contributed to particle pollution in Zhuzhou. Among these cities, Hefei had the largest contribution to atmospheric particles in the northeast air mass, and $\mathrm{PM}_{2.5}$ and $\mathrm{PM}_{10}$ are $70.4 \mu \mathrm{g} / \mathrm{m}^{3}$ and $110.8 \mu \mathrm{g} / \mathrm{m}^{3}$, respectively [34].

\section{Conclusions}

1) In Zhuzhou, the concentration of particulate matter smaller than $2.5 \mu \mathrm{m}$ accounted for $99.3 \%$ of the total concentration during summer, and the proportion of the fine particle with the size range below $1 \mu \mathrm{m}$ accounted for $72.3 \%$, and the $\mathrm{PM}_{2.5} / \mathrm{PM}_{10}$ ratio was $53.7 \%$, showing that Zhuzhou was mainly affected by fine particles.

2) Both the number concentration and mass concentration of particulate matter were affected significantly by rain. Because of the increase of relative humidity and the difference of hygroscopicity, the particle number concentration varied distinctly and increased more significantly in fine particles, especially at the size of $1-2.5 \mu \mathrm{m}$.

3) Backward trajectory analysis suggests that the air mass with the highest proportion was from the southeast direction of Zhuzhou City (52.2\%), followed by the southwest direction (24.7\%) passing the center of Guangdong Province and then the northeast direction (23.1\%). However, the air mass from the northeast direction made the greatest contribution to the particle concentration and also carried a lot of gaseous pollutants. The particle concentration in Zhuzhou was significantly affected by higher levels of particle concentration in the cities that the northeast air mass passed through; therefore, it is essential to strengthen the inter-regional joint air pollution prevention and control in the Chang-Zhu-Tan Metropolitan Region.

\section{Acknowledgements}

This work was supported by the National Science and Technology Support Program (No. 2014BAC06B01), the Natural Science Foundation of China (Nos. 41205093 and 41305124), the National Department Public Benefit Research Foundation (No. 201109005), and the Fundamental Research Funds for Central Public Welfare Scientific Research Institutes of China (No. 2016YSKY025). We are gratefully indebted to the staff of the Zhuzhou Environmental Monitoring Centers for their help and support during these experiments.

\section{References}

1. NEL A., XIA T., MÄDLER L., LI N. Toxic potential of materials at the nanolevel. Science, 311 (5761), 622, 2006.
2. RD P.C., BURNETT R.T., THURSTON G.D., THUN M.J., CALLE E.E., KREWSKI D., GODLESKI J.J. Cardiovascular mortality and long-term exposure to particulate air pollution: epidemiological evidence of general pathophysiological pathways of disease. Circulation, 109 (1), 71, 2004.

3. SHEN L., WANG H., LÜ S., LI L., YUAN J., ZHANG X., TIAN X., TANG Q. Observation of aerosol size distribution and new particle formation at a coastal city in the Yangtze River Delta, China. Science of the Total Environment, 565, 1175, 2016.

4. TAO M., CHEN L., XIONG X., ZHANG M., MA P., TAO J., WANG Z. Formation process of the widespread extreme haze pollution over northern China in January 2013: Implications for regional air quality and climate. Atmospheric Environment, 98, 417, 2014.

5. WOLF K., SCHNEIDER A., BREITNER S., MEISINGER C., HEIER M., CYRYS J., KUCH B., VON S.W., PETERS A. Associations between short-term exposure to particulate matter and ultrafine particles and myocardial infarction in Augsburg, Germany. International Journal of Hygiene \& Environmental Health, 218 (6), 535, 2015.

6. WANG H., AN J., SHEN L., ZHU B., CHEN P., LIU Z., LIU X., DUAN Q., XUAN L., WANG Y. Mechanism for the formation and microphysical characteristics of submicron aerosol during heavy haze pollution episode in the Yangtze River Delta, China. Science of the Total Environment, 490, 501, 2014.

7. ALFÖLDY B., GIECHASKIEL B., HOFMANN W., DROSSINOS Y. Size-distribution dependent lung deposition of diesel exhaust particles. Journal of Aerosol Science, 40 (8), 652, 2009.

8. BULLARD R.L., SINGH A., ANDERSON S.M., LEHMANN C.M.B., STANIER C.O. 10-Month characterization of the aerosol number size distribution and related air quality and meteorology at the Bondville, IL Midwestern background site. Atmospheric Environment, 154, 348, 2017

9. HUANG X., WANG C., PENG J., HE L., CAO L., QIAO Z., JIE C., WU Z., MIN H. Characterization of particle number size distribution and new particle formation in Southern China. Journal of Environmental Sciences, 51, 342, 2016.

10. ZHANG X., ZHANG Y., SUN J., ZHENG X., LI G., DENG $Z$. Characterization of particle number size distribution and new particle formation in an urban environment in Lanzhou, China. Journal of Aerosol Science, 103, 53, 2016.

11. ZHANG T., TAO J., WANG B.J., ZHANG R.J. Research on size distribution of particles and its impact on visibility in urban Guangzhou during spring. Journal of the Graduate School of the Chinese Academy of Sciences, 27 (3), 331, 2010 [In Chinese].

12. LANG F.L., YAN W.Q., ZHANG Q., CAO J. Size distribution of atmospheric particle number in Beijing and association with meteorological conditions. China Environmental Science, 33 (7), 1153, 2013 [In Chinese].

13. ZHAO S.P., YU Y., CHEN J.B., LIU N., HE J.J. Size distribution properties of atmospheric aerosol particles during summer and autumn in Lanzhou. Environmental Science, 33 (3), 687, 2012 [In Chinese].

14. LI R.P., SHI J.H., ZHANG D.Z. Size distribution of atmospheric particles in number concentration in relation to meteorological conditions and air mass origins in Qingdao in spring. China Environmental Science, 32 (8), 1392, 2012 [In Chinese]. 
15. YANG Q., ZHANG K., CAI F.H., LI J.S., ZHOU G.Z., ZHENG Z.L. Study on the pollution characteristics of atmospheric particles and heavy metals in autumn in ChangZhu-Tan metropolitan area. Research of Environmental Sciences, 26 (6), 590, 2013 [In Chinese].

16. ZHANG K., CHAI F., ZHENG Z., YANG Q., LI J., WANG J., ZHANG Y. Characteristics of atmospheric particles and heavy metals in winter in Chang-Zhu-Tan city clusters, China. Journal of Environmental Sciences, 26 (1), 147, 2014.

17. PRICE H.D., STAHLMECKE B., ARTHUR R., KAMINSKI H., LINDERMANN J., DÄUBER E., ASBACH C., KUHLBUSCH T.A.J., BÉRUBÉ K.A., JONES T.P. Comparison of instruments for particle number size distribution measurements in air quality monitoring. Journal of Aerosol Science, 76 (5), 48, 2014.

18. LIU Z.R., SUN Y., LI L., WANG Y.S. Particle mass concentrations and size distribution during and after the Beijing Olympic Games. Environmental Science, 32 (4), 913, 2011 [In Chinese].

19. WANG Y.Q., ZHANG X.Y., DRAXLER R.R. TrajStat: GIS-based software that uses various trajectory statistical analysis methods to identify potential sources from longterm air pollution measurement data. Environmental Modelling \& Software, 24 (8), 938, 2009.

20. FANG X., BI X., XU H., WU J., ZHANG Y., FENG Y. Source apportionment of ambient $\mathrm{PM}_{10}$ and $\mathrm{PM}_{25}$ in Haikou, China. Atmospheric Research, 190, 1, 2017.

21. DORLING S.R., DAVIES T.D., PIERCE C.E. Cluster analysis: A technique for estimating the synoptic meteorological controls on air and precipitation chemistryMethod and applications. Atmospheric Environment, 26 (14), 2575, 1992

22. WANG Q., JIANG N., YIN S., LI X., YU F., GUO Y., ZHANG R. Carbonaceous species in $\mathrm{PM}_{2.5}$ and $\mathrm{PM}_{10}$ in urban area of Zhengzhou in China: Seasonal variations and source apportionment. Atmospheric Research, 191, 1, 2017.

23. WANG X., CHEN J., CHENG T., ZHANG R., WANG $\mathrm{X}$. Particle number concentration, size distribution and chemical composition during haze and photochemical smog episodes in Shanghai. Journal of Environmental Sciences, 26 (9), 1894, 2014.

24. WANG A.P., ZHU B., YIN Y., JIN L.J., ZHANG L. Aerosol number concentration properties and potential sources areas transporting to the top of mountain Huangshan in summer. China Environmental Science, 34 (4), 852, 2014 [In Chinese].

25. MIKHAILOV E.F., MIRONOV G.N., PÖHLKER C., CHI X., KRÜGER M.L., SHIRAIWA M., FÖRSTER J.D., PÖSCHL U., VLASENKO S.S., RYSHKEVICH T.I., WEIGAND M., KILCOYNE A.L.D., ANDREAE M.O. Chemical composition, microstructure, and hygroscopic properties of aerosol particles at the Zotino Tall Tower Observatory (ZOTTO), Siberia, during a summer campaign. Atmospheric Chemistry and Physics, 15, 8847, 2015.

26. CHEN P., WANG T., LU X., YU Y., KASOAR M., XIE M., ZHUANG B. Source apportionment of size-fractionated particles during the 2013 Asian Youth Games and the 2014 Youth Olympic Games in Nanjing, China. Science of the Total Environment, 579, 860, 2016.

27. PANG X., MU Y., LEE X., ZHANG Y., XU Z. Influences of characteristic meteorological conditions on atmospheric carbonyls in Beijing, China. Atmospheric Research, 93 (4), 913, 2009.

28. PATERAKI S., MAGGOS T., MICHOPOULOS J., FLOCAS H. A., ASIMAKOPOULOS D.N., Ch, V. Ions species size distribution in particulate matter associated with VOCs and meteorological conditions over an urban region. Chemosphere, 72 (3), 496, 2008.

29. ZHAO S., YU Y., YIN D., HE J. Meteorological dependence of particle number concentrations in an urban area of complex terrain, Northwestern China. Atmospheric Research, 164-165, 304, 2015.

30. SU J., ZHAO P.S., CHEN Y.N. Characteristics of number concentration size distributions of aerosols under different weather processes in Beijing. Environmental Science, 37 (4), 1208, 2016 [In Chinese].

31. WU D., CAO S., TANG L., XIA J., LU J., LIU G., YANG M., LI F., GAI X. Variation of Size Distribution and the Influencing Factors of Aerosol in Northern Suburbs of Nanjing. Environmental Science, 37 (9), 3268, 2016 [In Chinese].

32. DAO X., ZHANG L.L., WANG C., CHEN Y., LYU Y.B., TENG E.J. Characteristics of mass and ionic compounds of atmospheric particles in winter and summer of BeijingTianjin-Hebei area, China. Environmental Chemistry, 34 (1), 60, 2015 [In Chinese].

33. ZHANG L.L., DAO X., WANG C., JIN X.W., TENG E.J., LU Y.B. Characterization of air particulate matters and elements in four national background locations, China. Environmental Chemistry, 34 (1), 70, 2015 [In Chinese].

34. CHEN G., LIU J.Y., HUANGFU Y.Q., WANG H.T., SHI G.L., TIAN Y.Z., ZHU Y., LI Q., FENG Y.C. Seasonal variations and source apportionment of ambient $\mathrm{PM}_{10}$ and $\mathrm{PM}_{25}$ at urban area of Hefei, China. China Environmental Science, 36 (7), 1938, 2016 [In Chinese].

35. ZHANG L.H., WU J.C., BAO Y.H., XU R., XU K. The analysis of pollution level of particles $\mathrm{PM}_{10}$ and $\mathrm{PM}_{25}$ in Wuhan and Xi'an. Air Pollution Control, 33 (3), 73, 2015 [In Chinese].

36. LUO Y.P., LIU M.J., GAN J., ZHOU X.T., JIANG M., YANG R.B. Correlation study on $\mathrm{PM}_{2.5}$ and $\mathrm{O}_{3}$ mass concentrations in ambient air by taking urban cluster of Changsha,Zhuzhou and Xiangtan as an example. Journal of Safety and Environment, 15 (4), 313, 2015 [In Chinese].

37. XIE C., ZHANG W.J., YANG W., LI W., WANG X.H., ZHAO X.Y., BAI Z.P. Pollution characteristics and health risk analysis of heavy metals in $\mathrm{PM}_{10}$ and $\mathrm{PM}_{2.5}$ in a triple cities area in Hunan Province. Journal of Environmental Engineering Technology, 6 (2), 147, 2016 [In Chinese].

38. SQUIZZATO S., CAZZARO M., INNOCENTE E., VISIN F., HOPKE P.K., RAMPAZZO G. Urban air quality in a mid-size city - $\mathrm{PM}_{25}$ composition, sources and identification of impact areas: From local to long range contributions. Atmospheric Research, 186, 51, 2017.

39. QIAN L., YIN Y., TONG Y.Q., WANG W.W., WEI Y.X. Particle size distribution of fine particulate matter in the northern suburb of Nanjing. China Environmental Science, 28 (1), 18, 2008 [In Chinese].

40. ZHUO Q.F., JIN L.J., LIN Z.Y., WU Z.H., KUANG S.S. Observational characteristic of aerosol number concentration and size distribution at Shijiazhuang in spring season. China Environmental Science, 31 (6), 886, 2011 [In Chinese].

41. YIN X., HUANG Z., ZHENG J., YUAN Z., ZHU W., HUANG X., CHEN D. Source contributions to $\mathrm{PM}_{2}$ in Guangdong province, China by numerical modeling: Results and implications. Atmospheric Research, 186, 63, 2017. 